\title{
Effect of dietary nitrogen source on carbohydrate metabo- lism in the rumen of the young steer
}

\author{
By A. B. McALLAN AND R. H. SMITH \\ National Institute for Research in Dairying, Shinfield, Reading RG2 $9 A T$
}

(Received I2 February 1976-Accepted 7 April 1976)

\begin{abstract}
I. Steers, fitted with simple rumen and duodenal cannulas, were given diets of approximately equal parts of flaked maize and hay (A) (containing $16 \mathrm{~g}$ nitrogen/kg dry matter (DM)) or diets of flaked maize and straw supplemented with decorticated groundnut meal (B), fish meal (C), or heated (D) or unheated (E) soya-bean meal (containing $24 \mathrm{~g} \mathrm{~N} / \mathrm{kg} \mathrm{DM}$ ). Chromic oxide was given as a marker with the feeds, and flows of different combined sugars at the duodenum estimated from the values for sugars: marker at this site. Contributions of bacterial constituents to these flows were estimated from amounts of RNA present.

2. Rumen bacteria from steers receiving diet A contained approximately i ro $g \alpha$-dextranglucose $/ \mathrm{kg}$ DM and contributed about $60 \mathrm{~g} \alpha$-dextran-glucose/d at the duodenum; bacteria

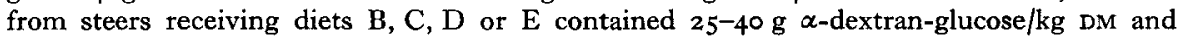
contributed about $20-3 \circ \mathrm{g} \alpha$-dextran-glucose/d at the duodenum. There were no significant differences between different $\mathrm{N}$ supplements. About half the $\alpha$-dextran-glucose, varying amounts of the mannose and galactose, and nearly all the rhamnose and ribose in duodenal digesta were contributed by the bacteria. Almost all the arabinose, xylose and celluloseglucose was of dietary origin.

3. For steers receiving diet $A$, mean coefficients of digestibility between mouth and duodenum, corrected where necessary for bacterial contribution, were $0.96,0.73,0.58,0.22$ and 0.53 for starch-glucose, galactose, arabinose, xylose and cellulose-glucose respectively. Corresponding mean values when diets $\mathrm{B}, \mathrm{C}, \mathrm{D}$ and $\mathrm{E}$ were given, which did not differ significantly amongst themselves, were $0.98,0.79,0.81,0.59$ and 0.58 . Most values for galactose, arabinose and xylose were significantly higher than the diet $A$ values.
\end{abstract}

There is considerable published information on apparent digestibilities of starch and fibre between the mouth and duodenum of the ruminant (e.g. MacRae \& Armstrong, 1969; Thivend \& Journet, 1970; Beever, Thomson, Pfeffer \& Armstrong, 197I). In some studies (Jarrige \& Minson, I964; Bailey \& MacRae, I970; Gaillard \& van't Klooster, 1973) cellulose and hemicellulose fractions, generally separated by taking advantage of solubility differences, have been studied individually and have usually been found to have similar digestibilities. There is some indication that the different monosaccharide constituents of the dietary hemicelluloses may be degraded to different extents (Bailey, 1967) but there is little information on such differences. There is also very little information on the ways in which digestibilities of individual constituents of the various dietary polysaccharides respond to variations in diet composition.

Interpretation of results for some constituents may be rendered difficult by uncertainty about the extent of the contribution of microbial matter to duodenal digesta. Most reported digestibilities for starch, for example, are expressed as net values and it is generally considered that the bacterial contribution is negligible. Studies with animals given all-roughage diets support this view. Thus, for example, Heald (195I) and Porter \& Singleton (I97I) found the amounts of microbial starch entering the small intestines of ruminants given such diets to be less than $6 \mathrm{~g} / \mathrm{d}$, and similar values 
Table I. Daily amounts* $(\mathrm{kg})$ of the components of cereal-roughage-based diets given to steers weighing ${ }_{1}^{16-1} 5^{8} \mathrm{~kg}$, together with total nitrogen and metabolizable energy (ME) contents

Component
Barley straw
Hay
Flaked maize
Decorticated groundnut meal
White fish meal
Heated soya-bean meal $\dagger$
Unheated soya-bean meal $\dagger$
Total N (g/kg DM)
ME (MJ $/ \mathrm{kg} \mathrm{DM})$

$\begin{array}{ccccc}\text { A } & \text { B } & \text { C } & \text { D } & \text { E } \\ - & 1.50 & 1.50 & 1.50 & 1.50 \\ 1.50 & -5 i e t & - & - & - \\ 1.56 & 1.30 & 1.30 & 1.30 & 1.30 \\ - & 0.64 & - & - & - \\ - & - & 0.56 & -7 . & - \\ - & - & - & 0.61 & 0.61 \\ 16 & 24 & 24 & 24 & 24 \\ 11.3 & 10.4 & 10.3 & 10.5 & 10.5\end{array}$

* These amounts were increased or decreased by about $120 \mathrm{~g} / \mathrm{kg}$ for each $20 \mathrm{~kg}$ difference in live weight.

+ The preparation of the heated soya-bean meal included a commercial toasting whereas the unheated soya-bean meal was isolated with the minimum amount of heating.

were estimated by Thompson \& Hobson (1971) from in vitro findings. However, for animals receiving large amounts of concentrates, Thompson \& Hobson (1971) concluded that microbial starch could be expected to contribute as much as $25 \mathrm{~g} / \mathrm{d}$. More recently, McAllan \& Smith (1974) estimated the contribution of microbial carbohydrates to total carbohydrates entering the duodenum of protozoa-free calves and calculated that for calves (approximately $160 \mathrm{~kg}$ body-weight) receiving diets containing $0.5^{-0.9} \mathrm{~g}$ concentrates/g intake, up to about $100 \mathrm{~g}$ bacterial $\alpha$-dextranglucose/d entered the duodenum.

The present study was undertaken to study the contribution of bacterial carbohydrates to duodenal carbohydrates and at the same time to determine the true digestibilities of the different combined dietary monosaccharides between mouth and duodenum. Comparisons were made between diets supplemented with different nitrogen sources and a diet providing a lower $\mathrm{N}$ intake.

\section{MATERIALS AND METHODS}

\section{Animals and diets}

Three Friesian steers, aged $34^{-52}$ weeks and weighing $127-195 \mathrm{~kg}$, were used in the experiments. They had been fitted with rumen cannulas and simple duodenal cannulas at $13-18$ weeks as described by Smith \& McAllan (1970). The steers all received initially either a basal diet of flaked maize and hay containing $16 \mathrm{~g} \mathrm{~N} / \mathrm{kg}$ dry matter (DM) (diet A, Table I) or one of the four diets (diets B-E) given in Table I, consisting of flaked maize, straw and a supplementary protein source (decorticated groundnut meal, fish meal, unheated or heated soya-bean meal, respectively), and containing $24 \mathrm{~g} \mathrm{~N} / \mathrm{kg}(\mathrm{DM})$. Diets were each given for a period of $24 \mathrm{~d}$ and in the following sequences: steer no. I, A, E, C, D, B, A; steer no. 2, A, C, E, D, B, A; steer no. 3, A, C, D, B, E (this steer lost its duodenal cannula before diet A could be 
repeated). The concentrate part of the diet was given in two equal portions at o9.00 and 17.00 hours and the roughage part was provided at 17.00 hours only. Shredded paper impregnated with chromic oxide was introduced into the rumen at each feed, at a rate of $0.85 \mathrm{~g} \mathrm{Cr}_{2} \mathrm{O}_{3} / \mathrm{kg} \mathrm{DM}$ intake, throughout the experimental period.

\section{Digesta collection}

Samples of rumen and duodenal digesta were collected as described by Smith \& McAllan (I970), on days 22 and 24 of each experimental period from each steer. Mixed bacteria were separated by the procedure of Smith \& McAllan (I974) from rumen digesta taken $4 \mathrm{~h}$ after the morning feed. Duodenal digesta samples were taken immediately before the morning feed and at $2 \mathrm{~h}$ intervals up to $8 \mathrm{~h}$, or in some experiments $24 \mathrm{~h}$ after that feed.

\section{Analytical methods}

Rhamnose, ribose, mannose, arabinose, galactose, xylose and $\alpha$-dextran-glucose were determined by ion-exchange chromatography of their borate complexes as described by Smith \& McAllan (I97I) in acid-hydrolysates (0.5 M-sulphuric acid) of mixed rumen bacteria, duodenal digesta and dietary components prepared as described by McAllan \& Smith (1974). Cellulose-glucose was estimated after more stringent acid-hydrolysis of the residue from the first hydrolysis, according to the procedure of McAllan \& Smith (1974). RNA was determined by the procedure of McAllan \& Smith (1969).

Chromium was estimated by the method described by Williams \& Smith (1974).

\section{RESULTS}

\section{Carbohydrate composition of dietary components and mixed rumen bacteria}

Values given in Tables 2 and 3 are the amounts of sugars released by acid-hydrolysis from samples of dietary components and mixed rumen bacteria respectively. For bacterial samples from steers receiving diet $A$ the mean amount of $\alpha$-dextran-glucose was II $3 \mathrm{~g} / \mathrm{kg} \mathrm{DM}$. For the protein-supplemented diets $\mathrm{B}, \mathrm{C}, \mathrm{D}$ and $\mathrm{E}$ the amount varied from 25 to $40 \mathrm{~g} / \mathrm{kg}$ DM. Differences between the different protein sources were not significant but all values were significantly lower $\left(P<0^{\circ} \mathrm{OI}\right)$ than that for diet $\mathrm{A}$. Amounts $(\mathrm{g} / \mathrm{kg} \mathrm{DM})$ of the other sugars in the bacterial samples indicated no significant differences related to diet. Arabinose and xylose were generally present in amounts less than $3 \mathrm{~g} / \mathrm{kg}$ DM and may have represented slight contamination with food material. Cellulose-glucose estimations were also carried out on a few samples for each diet but, as was found in earlier studies (McAllan \& Smith, 1974) the amounts present were less than $0.5 \mathrm{~g} / \mathrm{kg} \mathrm{DM}$ and were probably also due to food contamination.

\section{Contribution of bacterial carbohydrates to total carbohydrate entering the duodenum}

Estimates were made of the concentration of bacterial carbohydrates in duodenal digesta of the steers by measuring $(a)$ the ratio, RNA: carbohydrate for samples of mixed bacteria, and assuming this to be representative of the bacteria passing to the 


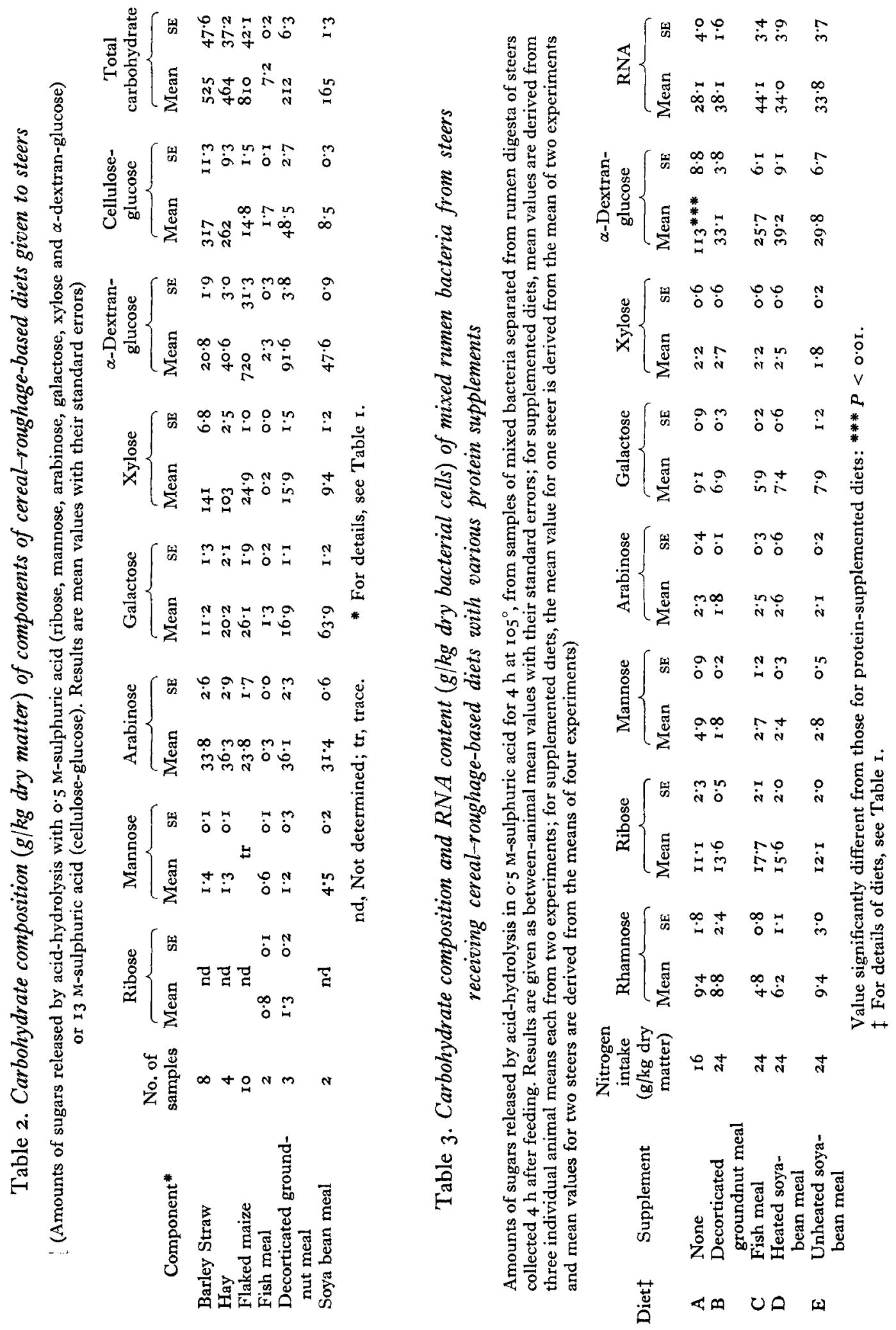


Vol. $3^{6}$

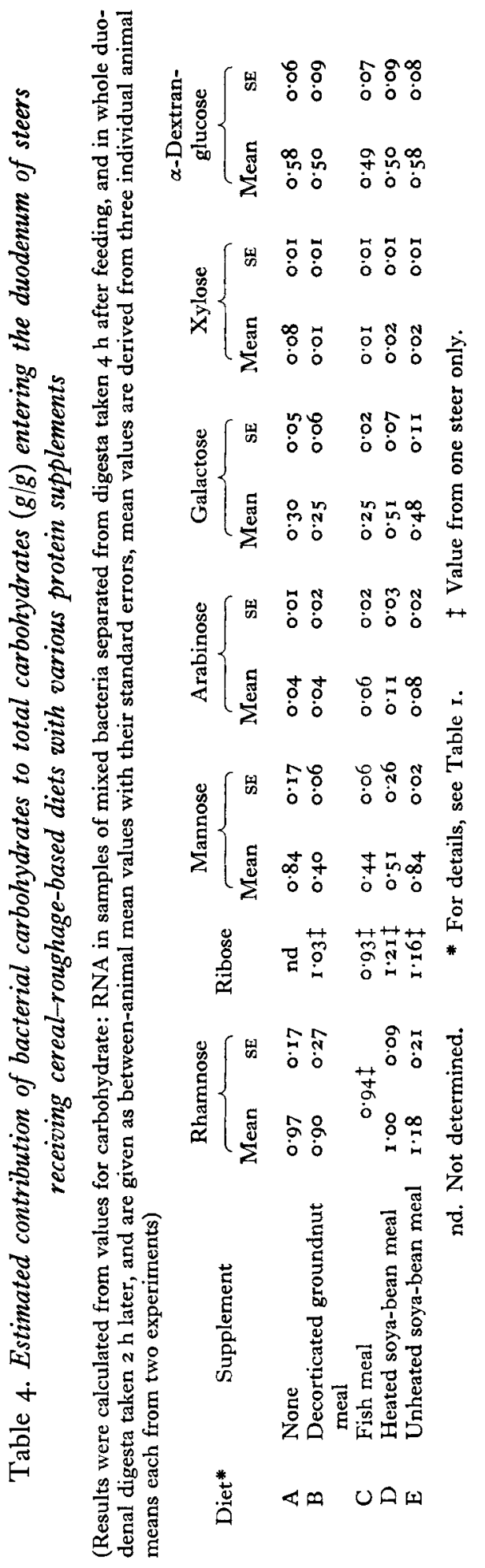


จ

है

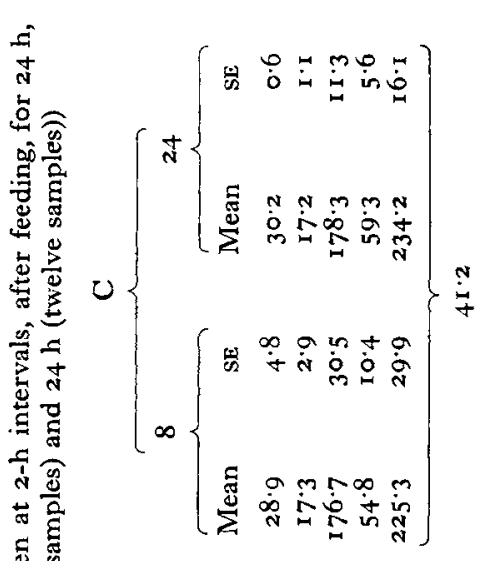

हิ

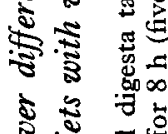
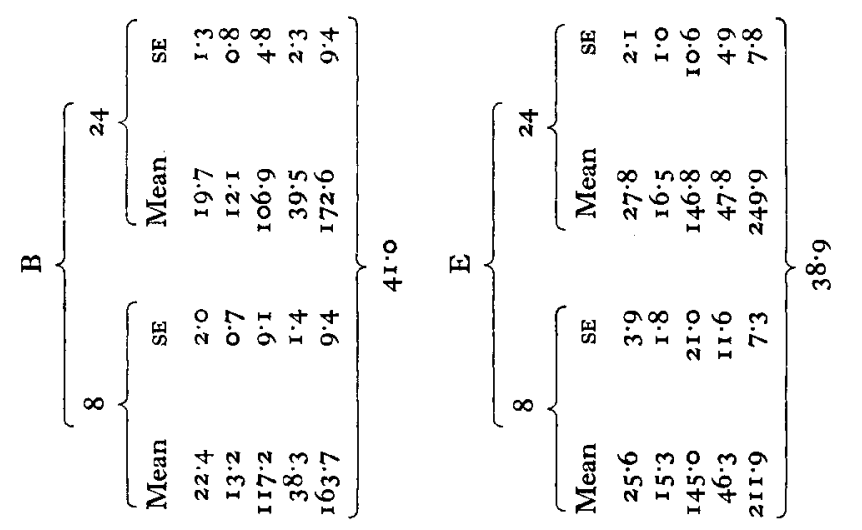

₹.

है ญั

के छ

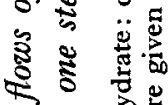

ㅎํ응

突金

₹ 5 要

टे क्षे

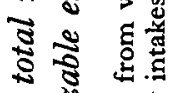

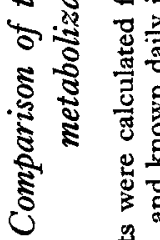

i
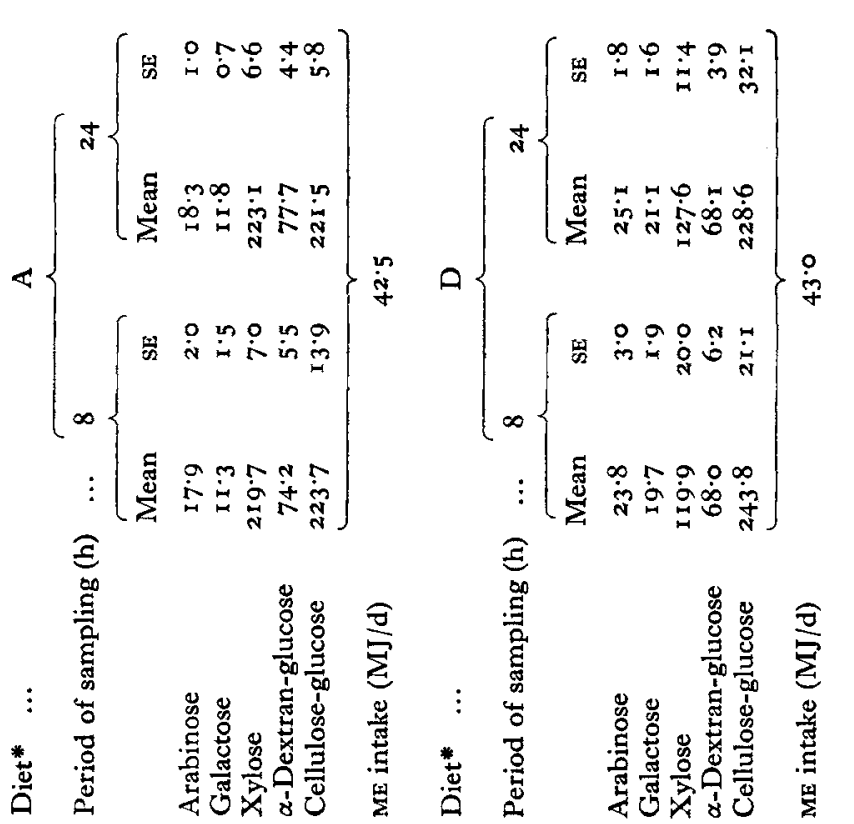

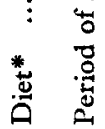

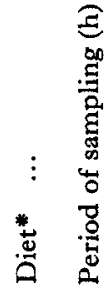

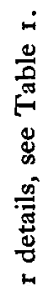

है 
duodenum; $(b)$ the concentration of RNA in digesta at the duodenum, and assuming this to be derived only from the rumen bacteria (McAllan \& Smith, 1974). It appeared from results given in Table 4 that all the rhamnose and ribose and much of the mannose came from the bacteria together with up to half the galactose and at least half the $\alpha$-dextran-glucose, while almost all the xylose, arabinose and cellulose-glucose was of dietary origin. There were no significant differences in estimated proportions provided by bacteria between the different diets for any of the carbohydrates studied.

\section{Carbohydrate flow at the duodenum}

Estimates of the total amounts of different carbohydrate components entering the duodenum in $24 \mathrm{~h}$ were obtained from the value for carbohydrate component: $\mathrm{Cr}_{2} \mathrm{O}_{3}$ for a number of duodenal samples, and the known $24 \mathrm{~h}$ intake for $\mathrm{Cr}_{2} \mathrm{O}_{3}$. For the experiments in which samples were taken at $2 \mathrm{~h}$ intervals over a whole $24 \mathrm{~h}$ period it can be assumed that the mean value obtained for carbohydrate component: $\mathrm{Cr}_{2} \mathrm{O}_{3}$ would be reasonably representative of that for the total flow. The results given in Table 5 for one steer indicate that values based on a mean value for the ratio for samples taken over $8 \mathrm{~h}$ periods were nearly identical to those based on $24 \mathrm{~h}$ collection periods. Similar results were obtained in six further experiments with the other two steers for all diets used. Many experiments were carried out, therefore, with only $8 \mathrm{~h}$ collections and results reported in Table 6 were obtained in this way. In Table 6 estimates have been made (from estimates of proportions of bacterial carbohydrate components obtained as described previously) of the amount of the flow of various carbohydrates at the duodenum which were of bacterial origin and, by difference, of dietary origin. From the latter, corrected values for rumen digestibilities of the different components were calculated.

Appreciable amounts of $\alpha$-dextran-glucose of bacterial origin entered the duodenum of steers receiving the unsupplemented $\operatorname{diet}(\operatorname{diet} A)$. Amounts were significantly less for the diets containing protein supplements (diets B-E) but there were no significant differences between protein sources. The amounts of other bacterial carbohydrates entering the duodenum were small and no significant differences, related to diet, were found.

Calculated amounts of residual dietary $\alpha$-dextran-glucose, galactose, arabinose and xylose entering the duodenum in $24 \mathrm{~h}$ (Table 6), were usually significantly greater for diet A than for diets B-E (Table 6) although intakes of galactose, arabinose and xylose were generally less for diet $\mathrm{A}$. For these latter sugars differences must therefore have reflected lower rumen digestibilities when diet A was given. Values for apparent and true (i.e. those corrected for microbial contribution, where necessary) digestibilities are also given in Table 6. Cellulose-glucose differed from the hemicellulose components, xylose and arabinose, as there were no appreciable differences in its digestibility in the rumen between the protein-supplemented diets and diet $\mathrm{A}$. 
芠

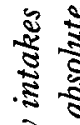

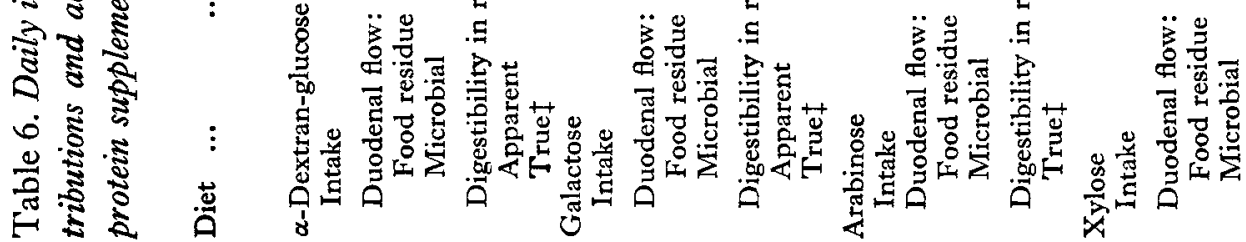


Vol. $3^{6}$

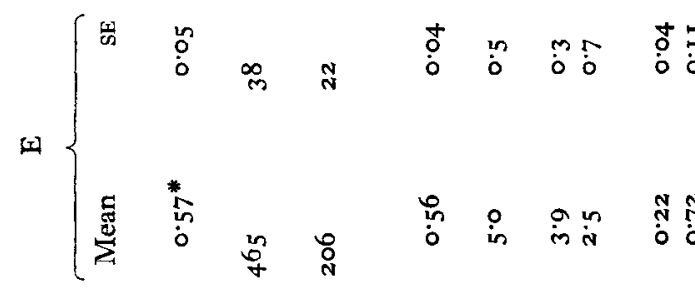

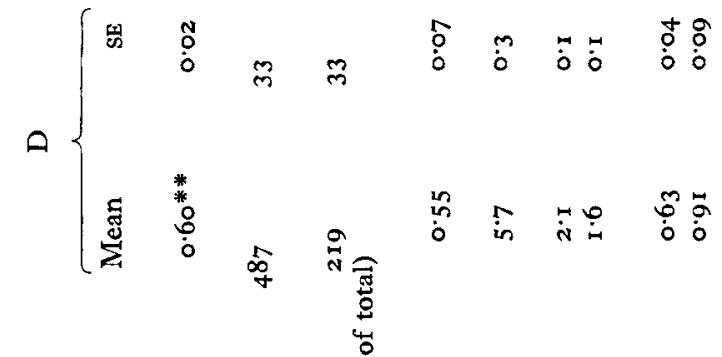

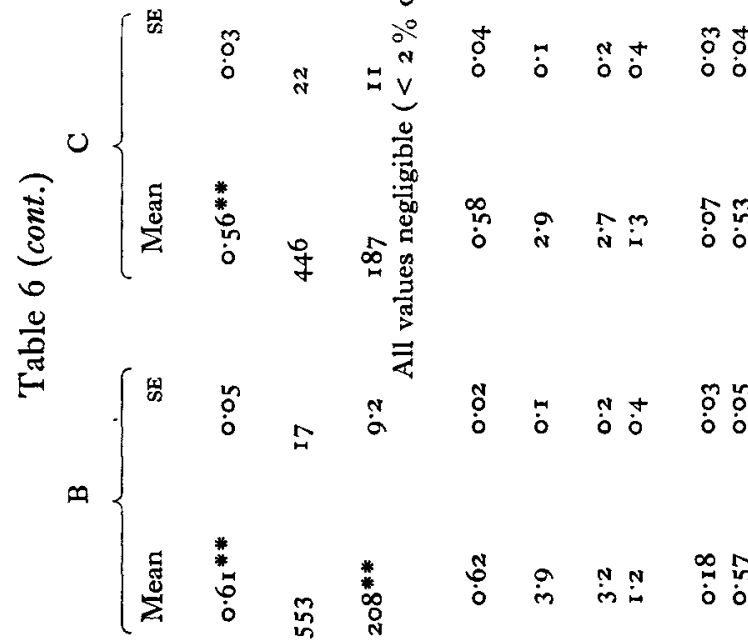

$$
\begin{aligned}
& \text { \% } \\
& \stackrel{\infty}{+\infty} \\
& \stackrel{m}{0} \\
& \stackrel{N}{0} \\
& \text { is } \frac{1}{2} \\
& \text { - } \\
& m^{\circ} \stackrel{5}{\frac{5}{5}} \\
& \text { 芩 } \\
& \text { ○ ․ㅗㅇ } \\
& \text { ค. E } \\
& \text { * } \\
& \text { बैं }
\end{aligned}
$$

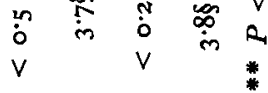

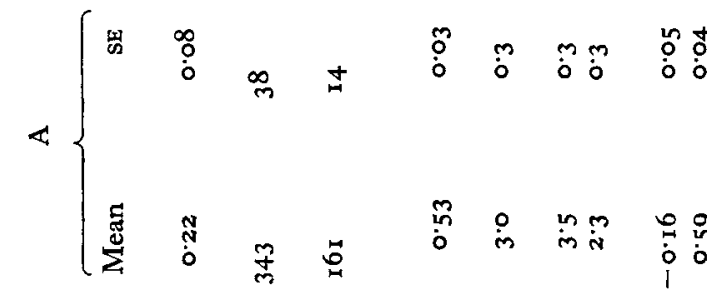

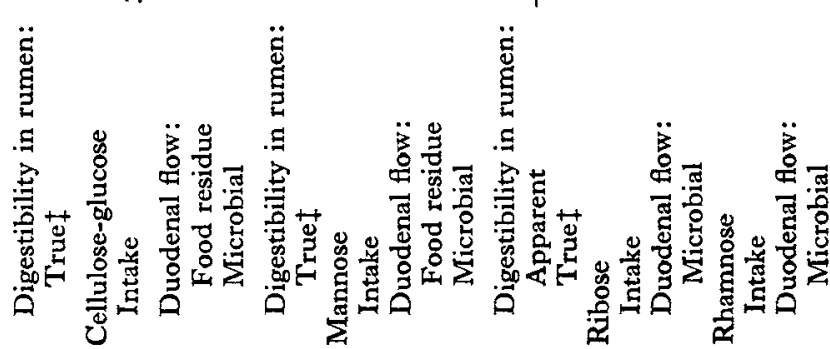

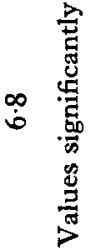




\section{DISCUSSION}

It was found previously (McAllan \& Smith, I974) that relatively large amounts of $\alpha$-dextran accumulated in mixed rumen bacteria when young steers received a low $\mathrm{N}$ intake. It seems probable that such accumulation occurs when excess energy is available to the bacteria and their growth is limited by the intake of degradable $N$ (Walker $\&$ Nader, 1970). If it is assumed that the mean degradability of the protein in flaked maize and hay is about $70 \%$ (Smith \& McAllan, unpublished results) and the $\mathrm{N}$ requirement for maximum microbial growth is $\mathrm{x} \cdot 66 \mathrm{~g} / \mathrm{MJ}$ metabolizable energy (Miller, 1973), then it can be calculated that microbial growth in the rumens of steers receiving diet $\mathrm{A}$ would be markedly $\mathrm{N}$-limited. The fact that all the protein-supplemented diets led to rumen bacteria with lower $\alpha$-dextran contents than did diet A indicated that all probably provided adequate supplements of degradable $\mathrm{N}$ for microbial growth. Such a decrease in the $\alpha$-dextran-glucose content of rumen bacteria was not found in another similar experiment in which formaldehyde-treated casein formed the protein supplement (Williams, McAllan \& Smith, I973). The finding that a fishmeal supplement produced effects similar to those obtained with supplements of decorticated groundnut meal or soya-bean meals is consistent with our findings (McAllan \& Smith, unpublished results) based on RNA and $\alpha, \epsilon$-diaminopimelic acid flows at the duodenum, indicating that this sample of fish meal was extensively (about $70 \%$ ) degraded in the rumen of the steer. This was in apparent disagreement with reports that fish-meal is very resistant to degradation in the rumen of sheep (Miller, I974), possibly because of animal differences or because different types of fish meal were used.

The method used to estimate microbial contributions to carbohydrates in duodenal digesta, based on measurements of RNA as a reference material in bacteria and digesta samples, was described previously and its validity discussed (McAllan \& Smith, 1974). The presence of protozoa in the rumens of steers used in the present experiments may have affected the amounts of RNA and carbohydrate components at the duodenum to some extent but the effects were probably small as protozoal counts were generally low (37000-140000 counts/ml rumen fluid). Calculated contributions of microbial $\alpha$-dextran-glucose and galactose at the duodenum for diet $\mathrm{A}$ were, in fact, closely similar to those found previously for protozoa-free calves receiving similar diets (McAllan \& Smith, I974). Thus, although the present estimates of bacterial carbohydrates entering the duodenum cannot be expected to be highly accurate, because bacterial preparations obtained from rumen fluid are unlikely to represent exactly the bacteria passing to the duodenum, it appears that they should be approximately correct.

Present findings supported earlier findings (Thompson \& Hobson, 1971; McAllan \& Smith, 1974) indicating that bacterial components may sometimes make a considerable contribution to the $\alpha$-linked glucose polymers and galactosecontaining polymers entering the duodenum of the ruminant. The present results agree with other reports for diets containing considerable amounts of most types of cereals (Armstrong, 1974) that apparent digestibilities of starch between 
mouth and duodenum are high even for fairly low $\mathrm{N}$ intakes (Ørskov, Fraser \& McDonald, I97I) but they also indicate that true digestibilities are even higher.

Differences in digestibilities of cellulose and hemicellulose constituents between mouth and duodenum for steers given $\operatorname{diet} \mathrm{A}$ and the protein-supplemented diets were probably influenced in part by the inclusion of hay in diet $A$ and straw in the protein-supplemented diets. However, supplementing low- $\mathrm{N}$ diets with a $\mathrm{N}$ source has been found to lead to increased fibre (Campling, Freer \& Balch, 1962) and cellulose digestion (Ammerman, Verde, Moore, Burns \& Chicco, 1972; Winter \& Pigden, 1971) between mouth and duodenum, and many of the differences in digestibilities found in the present studies were probably due to differences in $\mathrm{N}$ intake.

Published values for digestibilities, up to the duodenum, of dietary cellulose and hemicellulose containing fractions (e.g. Balwani, Johnson \& Dehority, 1969; MacRae \& Armstrong, 1969; Gaillard \& van't Klooster, 1973) have generally been found to be broadly similar to the values found in the present studies (assuming the sum of galactose, arabinose and xylose digestibilities to represent hemicellulose digestibility). There are, however, few published values for relative digestibilities of the individual monosaccharide components of these carbohydrates up to the duodenum, although Bailey (1967) reported that the arabinose and galactose in dietary hemicelluloses were degraded in the rumen more rapidly than the xylose. The present findings (Table 6) indicated that for steers given diet A the digestibilities of individual monosaccharide components differed considerably and decreased in the order: galactose, arabinose, cellulose-glucose, xylose. Digestibilities in animals transferred from diet $\mathrm{A}$ to the protein supplemented diets (which did not differ significantly amongst themselves) increased but to greatly differing extents so that, for example, digestibilities of xylose more than doubled while that of cellulose-glucose increased only slightly.

Fermentation of starch provided the greatest amount of energy for the rumen bacteria on all diets. It is known that under these circumstances digestion of celluloses and hemicelluloses may be reduced (MacRae \& Armstrong, 1969; Thivend \& Journet, 1970) but they were nevertheless fermented to considerable extents. In absolute terms, amounts ( $\mathrm{g} / \mathrm{d})$ of galactose, arabinose, xylose and cellulose-glucose fermented by the rumen bacteria were $38,45,38$ and 182 respectively for diet $A$ and as an average $58,77, \mathrm{I}_{42}$ and 283 for the protein-supplemented diets. Thus not only the total energy but the relative amounts of monosaccharides providing that energy differed for the two types of diet. Different monosaccharides may be used with differing efficiencies in providing energy for the synthesis of bacterial protein or other organic matter (Henderickx, Demeyer \& Van Nevel, 1972), so such variations may lead to differences in the extent of bacterial growth in the rumen supported by a particular energy expenditure.

We thank Dr H. L. Buttle and Mr S. C. Watson for carrying out all surgical operations, Mrs S. J. Askew for the care and maintenance of the steers, and Miss P. E. Lewis and Mr R. J. Merry for skilled technical assistance. We also thank the British Arkady Co. Ltd, Manchester, for their kind gifts of the soya-bean meals. 


\section{REFERENCES}

Ammerman, C. B., Verde, G. J., Moore, J. E., Burns, W. C. \& Chicco, C. E. (1972). J. Anim. Sci. 35, 121.

Armstrong, D. G. (1974). Cereal Supply and Utilization, p. 2 I. London: US Feed Grains Council.

Bailey, R. W. ( 1967). N.Z. Yl agric. Res. ro, 15.

Bailey, R. W. \& MacRae, J. C. (r970). F. agric. Sci., Camb. 75, 32 r.

Balwani, T. L., Johnson, R. R. \& Dehority, B. A. (1969). F. Dairy Sci. 52, 129o.

Beever, D. E., Thomson, D. J., Pfeffer, E. \& Armstrong, D. G. (197I). Br. F. Nutr. $26,123$.

Campling, R. C., Freer, M. \& Balch, C. C. (1962). Br. F. Nutr. 16, I 5.

Gaillard, B. D. E. \& van't Klooster, A. Th. (1973). Neth. F. agric. Sci. 21, 217.

Heald, P. J. (1951). Br. F. Nutr. 5, 84.

Henderickx, H. K., Demeyer, D. I. \& Van Nevel, C. J. (1972). Tracer Studies on Non-Protein Nitrogen for Ruminants, p. 57. Vienna: International Atomic Energy Agency.

Jarrige, R. \& Minson, D. J. (I964). Annls Zootech. 13, II7.

McAllan, A. B. \& Smith, R. H. (1969). Br. F. Nutr. 23, 671.

McAllan, A. B. \& Smith, R. H. (1974). Br. Y. Nutr. 31, 77.

MacRae, J. C. \& Armstrong, D. G. (1969). Br. F. Nutr. 23, 377.

Miller, E. L. (1973). Proc. Nutr. Soc. 32, 79.

Miller, E. L. (1974). British Fishmeal in Animal Nutrition, p. 37. London: Vale Press Ltd.

Ørskov, E. R., Fraser, C. \& McDonald, I. (1971). Br. J. Nutr. $25,225$.

Porter, P. \& Singleton, A. G. (1971). Br. F. Nutr. 26, 75.

Smith, R. H. \& McAllan, A. B. (1 970). Br. F. Nutr. 24, 545.

Smith, R. H. \& McAllan, A. B. (197r). Automation in Analytical Chemistry (Technicon Symposium, 1969) p. 207. Basingstoke, Hants: Technicon Instruments Company Ltd.

Smith, R. H. \& McAllan, A. B. (1974). Br. F. Nutr. 3r, 27.

Thivend, P. \& Journet, M. (1970). Annls Biol. anim. Biochim. Biophys. 1o, 323.

Thompson, J. K. \& Hobson, P. N. (1971). Y. agric. Sci., Camb. 76, 423.

Walker, D. J. \& Nader, C. J. (1970). Aust. F. agric. Res. 2., 747.

Williams, A. P., McAllan, A. B . \& Smith, R. H. (1973). Proc. Nutr. Soc. 32, 85 A.

Williams, A. P. \& Smith, R. H. (1974). Br. F. Nutr. 32, 42 I.

Winter, K. A. \& Pigden, N. J. (1971). Can. Y. anim. Sci. 51, 777. 